\title{
Brian Tracy, Something for Nothing, Why We Do the Things We Do. Jaico Publishing House, Mumbai, 2009, reprint 2011, p. 245, ISBN: 9788184950564
}

Reviewer: Mangasini Katundu

Received: Nov. 24, 2018 Accepted: Dec. 10, 2018 Published: Dec. 21, 2018

doi:10.5296/bmh.v6i2.14084ＵRL: http://dx.doi.org/10.5296/bmh.v6i2.14084

\section{Synopsis and Evaluation}

In his book Tracy discusses "the something for nothing" syndrome, he answers the main question, "why we do the things we do?" The author associates what we do the things we do with what he called "human nature", that every individual has both the "bright side" and a "dark side" of his nature, an angel and a devil. According to the author these two forces compete continually in an individual's mind and heart and hence, they control individual's thoughts, feelings and actions (p. 2). He reminds everyone that, real life is different from dreams; people have various sweet dreams which sometimes may not come true. Life is difficult; we need to work hard to realize our dreams.

The author has organized his book into twelve chapters which are preceded by a brief introduction. Tracy emphasizes that, "the something for nothing disease is like a cancer that can begin with a single cell, or a single opportunity to get "free money" in some way, and which then grows into a tumor... the something for nothing epidemic, cancer, virus, or germ usually starts in the greedy and avaricious nature of immoral people eager to enrich themselves at the expenses of other. It is the driving force behind almost every form of unhappiness, corruption, criminality, and anti-social-behaviour" (pp. ix-x). He reminds everybody that we should avoid short cuts, fastest and easier routes; we should as well be concerned about long-term consequences of our actions. What Tracy is essentially saying is, do not abuse human rights now because you can end up spending most of your last years in prison. African leaders like, DRC's Jean Pierre Bemba (AFP, 2018) and the former Ivorian President Laurent Gbagbo (Open Society Justice Initiative, 2016) would have not been tried by the International Criminal Court (ICC) if they would have respected human rights. Likewise, most youth today gather wealth illegally and end up in prison. Same applies to Mr. Jacob Zuma and Thabo Mbeki, the two former Presidents of the Republic of South Africa. 
Zuma engineered the removal of Mbeki into power in 2008 (The Guardian, 2008) without minding its long-term consequences. Ten years later in 2018 Zuma was forced to resign by his own Party ANC the same way he removed Mbeki (BBC, 2018).

This book is a very good resource for academicians, entrepreneurship trainers, students and motivational speakers. It is also an important book for parents and politicians alike. The book highlights various reasons as to why we do the things we do and what makes us not do the things we don't. It also highlights effects of people striving to get the things they want in the fastest and easiest way possible without minding the long-term consequences of their actions. Even if the author does acknowledge that there are many factors that shape the "human actions" he essentially explains endogenous factors alone and ignores exogenous factors. The bright and dark sides of any individual are moderated by the exogenous (environmental) factors. No one is born corrupt but is corrupted by the society in which he lives. Our spouses, close relatives, office mate and friends tend to shape our behaviour. We do what we do because sometimes we are being advised that way by people we value very much. A political leader for example, he enters into the office as ethical and clean man, after persistent pressure from relatives and close friends he starts to change to satisfy their needs. In most cases requests from family and relatives by far exceed what the officer earn. Corruption becomes the easiest solution to gain more money to meet the family needs.

The Theory of Planned Behaviour (TPB) by Ajzen (1991) postulates that "human behaviour (action) is planned". According to this theory there are three factors which influence the decision of individual namely attitudes, perceived behavioral control, and subjective norms. Attitudes refer to the degree to which a person has a favorable appraisal of the behaviour (is it good?). Subjective norm refers to the perceived social pressure to perform the behaviour (extended family, office mates and friends). Perceived behavioral control refers to the perceived ease of performing the behaviour (Can I do it?) and to the perceived control over the outcome of it (will I be able to face the consequences?). That is, whenever our attitudes lead us to do one thing but the relevant norms may suggest we should do something else, both factors influence our behavioral intent. Another weakness of the book is overemphasis on America and Americans; despite having a good theme and contents. The author dedicates entirely three chapters five, six and twelve for America and Americans; it is as if he was speaking to Americans only. This book ought to have been a global resource book.

\section{In the Author's Own Words}

... "What we know is that everyone is lazy, greedy, ambitious, and impatient. This applies to every person, everywhere, in all circumstances. These qualities are neither good nor bad in themselves. They are neutral. ... For example, if laziness is demonstrated by finding faster, better, cheaper, easier ways to accomplish tasks and achieve goals, which is the motive force behind all advancement in human civilization, then laziness, is a good thing"(p. 4). ... "if people's natural laziness causes them to slack off, cut corners, avoid work, and fail to complete tasks. Waste time, starts later and leaves earlier, and generally contributes less to their jobs and families, then laziness is bad.” ... (p. 5). 


\section{Macrothink}

\section{Reviewer's Details}

Dr. Mangasini Katundu is a senior lecturer at the Moshi Co-operative University (MoCU), Moshi, Tanzania. He specializes in the fields of rural development and entrepreneurship. E-mail: mangasini.katundu@mocu.ac.tz and atanasi.mangasini@gmail.com

\section{References}

AFP. (2018). ICC to sentence DRC's Bemba in bribery case. Retrieved from https://www.news24.com/Africa/News/icc-to-sentence-drcs-bemba-in-bribery-case-20180917

Ajzen, I. (1991). The theory of planned behaviour. Organizational Behaviour and Human Decision Processes, 50(2), 179-211. https://doi.org/10.1016/0749-5978(91)90020-T

BBC. (2018). South Africa's Jacob Zuma resigns after pressure from party. Retrieved from https://www.bbc.com/news/world-africa-43066443

Katundu, M. A., \& Gabagambi, D. M. (2016). Barriers to Business Start-up among Tanzanian University Graduates: Evidence from the University of Dar-es-Salaam. Global Business Review, 17(1), 16-37. https://doi.org/10.1177/0972150915610667

Open Society Justice Initiative. (2016). The Trial of Laurent Gbagbo and Charles Blé Goudé at the ICC. Briefing Paper. Retrieved from https://www.opensocietyfoundations.org/sites/default/files/briefing-gbagbo-FINAL-2016012 $1 \% 20(1) \cdot p d f$

The Guardian. (2008). Thabo Mbeki to step down as South African president after ANC request. Retrieved from https://www.theguardian.com/world/2008/sep/20/southafrica1

\section{Copyrights}

Copyright for this article is retained by the author(s), with first publication rights granted to the journal.

This is an open-access article distributed under the terms and conditions of the Creative Commons Attribution license (http://creativecommons.org/licenses/by/4.0/). 